\title{
Aytekin Karacoban
}

\section{Entrevista con Pablo Neruda ${ }^{1}$}

Aytekin Karacoban es poeta y traductor, nacido en Turquía en 1958. Karacoban trabajó en la Facultad de Educación de Dicle en Diyarbakir. Después de haber finalizado sus estudios en esta Universidad, en 1985, obtuvo el Diploma de Estudios Superiores en la Universidad de Rouen (Francia), para lo cual investigó sobre la poesía de la Resistencia francesa. Aytekin vive en Francia desde 1990.

Karacoban ha publicado desde 1978 poemas y artículos en numerosas revistas literarias de su país de origen. Ha traducido poemas, artículos y libros de poetas y escritores contemporáneos. Publica igualmente en revistas literarias en Francia.

Sus obras son Ben Gülün Kardeşiyim (Yo soy hermano de la rosa), Ankara, 1988; Pablo Neruda 'yla Söyleşi (Entrevista con Pablo Neruda), Stockholm. 1995; Anlık Görüntüler (Imágenes instantáneas), Ankara, 1998; Kavuşma Tadında (En el gusto de los encuentros), Ankara, 2000; Yüksek Gerilim Hattı (Línea de alta tensión), Ankara, 2015.

${ }^{1}$ Las traducciones del turco al francés son del autor, y del francés al español son de Mercedes Vázquez y sus correcciones del poeta Karacoban. 
¿Por qué no ataca el tiburón

a las impávidas sirenas?

Si no existieran

El tiburón no tendría fidelidad, ni amor por el agua

Ni tendría amadas que hicieran guardia

Delante de sus puertas.

¿Qué dice la vieja ceniza

cuando camina junto al fuego?

Si buscáis pruebas

miradme un poco el rostro

Soy el único cuerpo del delito

Atizad un poco.

Y la tortuga preguntó :

¿Qué conversas con las naranjas?

En sus pelotas anaranjadas está el agua

Que destilaron del sudor del Mediterráneo

Luego las azucararon.

¿Por qué lloran tanto las nubes

y cada vez son más alegres?

La inmigración que los vientos violentos imponen

Espera siempre lista delante de su puerta

Ellas son separación y reencuentro

Y saben, mejor que nadie, hilar con su lana

El hilo que une al cielo y la tierra. 
¿Por qué el sombrero de la noche vuela con tantos agujeros?

Ha de avisarles a los países

Que un día más termina de nuevo

Ordeña el descanso de sus agujeros

Sobre los lechos de las casas cansadas

$\mathrm{Su}$ sombra es desigual

Tapando las fealdades

Allí donde la suciedad

Se desparrama escondida

Allí donde los señores impregnados de intrigas

Beben en copas de oro

El jugo que sacan de la uva de la vida

Allí donde miran, borrachos, las vides a través de sus bolsillos

Allí donde sólo quedan para los demás

El residuo y algunas uvas verdes.

\section{¿Qué dirán de mi poesía}

los que no tocaron mi sangre?

Dirán muchas cosas, don Pablo, pero no hablarán de los ríos de Chile que corren por las venas de tu poesía. 


\section{¿Por qué los inmensos aviones}

no se pasean con sus hijos?

Una niña con la falda embebida de azul :

He aquí un ejemplo de la irresponsabilidad de los adultos.

Un estudiante que va a pasar sus exámenes :

¿Qué nota me pondrá?

Una madre que tiene a su hijo en el ejército :

Son niños de hoy, hijo mío,

a quienes les gusta jugar a la guerra,

que sus alas caigan

y que no toquen a nuestros hijos.

Un hombre borracho perdido :

Estoy tan ebrio

Que los inmensos aviones no compiten conmigo,

Poco me importan

ellos y sus hijos.

\section{¿Comó se mide la espuma que resbala de la cerveza?}

Se mide con los encajes que las muchachas ebrias de amor tejen para sus alcobas.

Con los besos blancos que el mar lleva a las costas en sus olas.

Con las flores que un árbol ofrece a las abejas antes de ofrecerse a las frutas.

Con la nostalgia que sube al corazón de los que acechan el camino. 
¿Por qué en las épocas oscuras

se escribe con tinta invisible?

Bajo la pesada carga

La vida camina completamente desnuda

Descalza por las calles pedregosas

Cuando el país rodeado de amor se reduce

El deslizamiento de una mano hacia otra

De una lengua hacia otra

Es un faro para nuestros barcos

Hacemos de cada ramo de luz una pluma

Para escribir humedeciéndola en la tinta del mar.

¿Qué dijeron los rubíes

ante el jugo de las granadas?

Aprendimos a no ser estrujados

Nadie puede quitarnos el jugo de nuestra belleza

Que destilamos con paciencia y resistencia

Tú lo llamas egoísmo

Nosotros protección de nuestro sudor.

¿Cómo se reparten el sol

en el naranjo las naranjas?

Amistosamente.

Si no lo hicieran

Unas estallarían de demasiado sabor

Y las demás, desabridas.

\section{¿Qué hace una mosca encarcelada} en un soneto de Petrarca?

Se cansa de aletear

Y sólo se enferma a sí misma. 
¿Por qué se suicidan las hojas

cuando se sienten amarillas?

Así pagan

$\mathrm{Su}$ fidelidad a las leyes de la naturaleza.

Dime, ¿la rosa está desnuda

o sólo tiene ese vestido?

Como tú ves

Estoy bien vestida

Mi ropa es mi desnudez.

¿Cómo se llama ese coctel

que mezcla vodka con relámpagos?

Se vuelve ciclón

Aullando, hostigando a los hombres,

Corriendo descalzo por las calles

Con sus locas canciones.

¿Con las virtudes que olvidé

me puedo hacer un traje nuevo?

Tejiste con tus virtudes

La trama universal de tu poesía chilena

Nos las dejaste

Con ella, nos hacemos ropas

Y no hay nadie más hermoso que nosotros

En las fiestas poéticas

Engalanaste tu voz con tus virtudes

Es su chalina de seda

Que se vuelve canciones

Cuando pasa rozando nuestras ramas. 


\section{¿Y para qué tantas arrugas y tanto agujero en la roca?}

Las aguas no soportan la calma

Querían crecer

Llegaron al mar en afluente

Olvidando quedarse prisioneras

En la mano de la tierra

Se lanzan hacia las rocas

En la nostalgia de los montes

Muy apretadas con el viento

Golpean como mazos

Su puño que se quiebra cada vez

Afilan con sus aullidos,

los dientes sin descanso

Hay algo que no entiendo, maestro,

Se llevan las migajas que arrancan a las rocas

Para desgranarlas en las dunas de otras orillas

Es una señal que dejan

Para no perder el camino. 


\section{¿Y cómo saben las raíces \\ que deben subir a la luz?}

Las ramas que levantaron los brazos al cielo

Se vuelven tan conductoras de tanto hacer el amor con el sol

Que envían a las raíces la alegría luminosa

Es otra manera de retornar

La leche que maman de la tierra

Y si las raíces no supieran salir a la luz

La enfermedad habría hinchado

Sus pulmones como patatas.

\section{¿Cuántas iglesias tiene el cielo?}

Tantas iglesias como estrellas

Bajo la cúpula

Adonde nadie va a orar

Sólo la luna las visita una por una

Cada noche para encender las velas

Con fósforos prestados por el sol

Cuelgan en racimos

En el camino de los viajeros nocturnos

Para dar un gusto más sabroso

Con sus labios prestos al vino

Pero también tienen la mala costumbre

De delatar

A los fugitivos en las fronteras. 


\section{Cuando ya se fueron los huesos, ¿quién vive en el polvo final?}

Los gusanos que se alimentan de nuestra carne bajo tierra Visten nuestros huesos con su carne

Para hacer del hombre un gusano para el hombre

Sólo el gusano vive en el pantalón del hombre

Es el hombre con cerebro de gusano.

\section{¿Cuál es el trabajo forzado de Hitler en el infierno?}

Forzado a errar sin sentir

El amor humano florecido en su tierra

Forzado a oír levantarse desde el fondo de las casas que arrasó Las canciones que no pudo quemar

Sin criado, sin esclavo, desnudo, forzado a buscar su alma A hundir sus manos en la sangre y la ceniza de los que asesinó

Forzado a ver caer sobre él

el fuego de las lenguas y de las armas

De las víctimas que no pudo exterminar. 
¿Y con qué cifras va restando

la hormiga sus soldados muertos?

Miedosa y precipitada

Lleva la carroña de los soldados muertos

A su país de hormiga

Y después de acabar su trabajo

De enjugarse el sudor

hace las cuentas

Con el botín que consiguió en la guerra

Llena cuatro graneros.

¿Cuándo lee la mariposa

lo que vuela escrito en sus alas?

Página tras página gira sus alas volando

Para que la primavera escriba con su lápiz multicolor

Como no logra leerlo por sí misma

Pide a las flores en las que se posa

Lo que va escrito en su página abierta. 


\section{¿Cómo se llaman los ciclones cuando no tienen movimiento?}

Es un perro obedeciente

Que se echa a los pies de su amo

Después de enseñar los colmillos

$\mathrm{Y}$ atacar a cuantos ha encontrado

Es el verdugo que en su casa desempeña

El papel de esposo y padre apacible

Después de tantas y tantas torturas

Es ese hombre duro con los suyos

$\mathrm{Y}$ esclavo delante de su amo

Es la fuerza salvaje de la guerra

Que revienta al acosar la hija de la paz

\section{¿La oceanía de los aires}

no tiene islas y palmeras?

Las islas diseminadas en el océano del cielo

No van atadas por la cola, menos mal,

¿Qué triste sería!

De día el cielo cubre con su tul azul

La cuna donde descansan bellamente

De noche salen de paseo

Alumbrando las aguas con sus antorchas. 
¿De qué se ríe la sandía

cuando la están asesinando?

Va destilando su jarabe campesino del agua y de la tierra

Durante la temporada que pasa tendida

Primero le da su sabor al cuchillo

Como si hubiera colmado así una nostalgia

Si vieras, maestro,

La sandía de Diyarbakir que revienta riendo sin cuchillada

Que va creciendo cada día más en su gorda faz

Las risas mesopotámicas que pide prestadas del Tigre

Meciéndose en la cuna de la arena.

¿Cuántas semanas tiene un día

y cuántos años tiene un mes?

Hay que preguntárselo

A los que acechan el camino

De sus amantes

Y también a los presos.

\section{¿Qué aprendió el árbol de la tierra para conversar con el cielo?}

La tierra transforma, comenta a su antojo las palabras Que pide a la lengua del cielo

Cada árbol coge de allí, con sus raíces, lo que quiere

Por eso unos tienen lenguas como agujas

Y los demás, como manos que abofetean

Pura miel goteando

$\mathrm{Ni}$ el cielo ni la tierra habían pensado en esto

Cuando creaban su idioma común. 
Poligramas 43 - diciembre de 2016

\section{¿Cómo conocieron las uvas \\ la propaganda del racimo?}

Para ver eso hay que ir a Burdeos

Donde las uvas ennegrecen mirando la rosa

La cabeza de la rosa está puesta en el altar

En la punta de las líneas de viña

Si el hacha de la enfermedad no baja hasta su cuello

La uva puede tomar su sitio, tranquila, en el racimo

No conoce la propaganda del racimo

Por el perfume sino por el miedo de la rosa. 